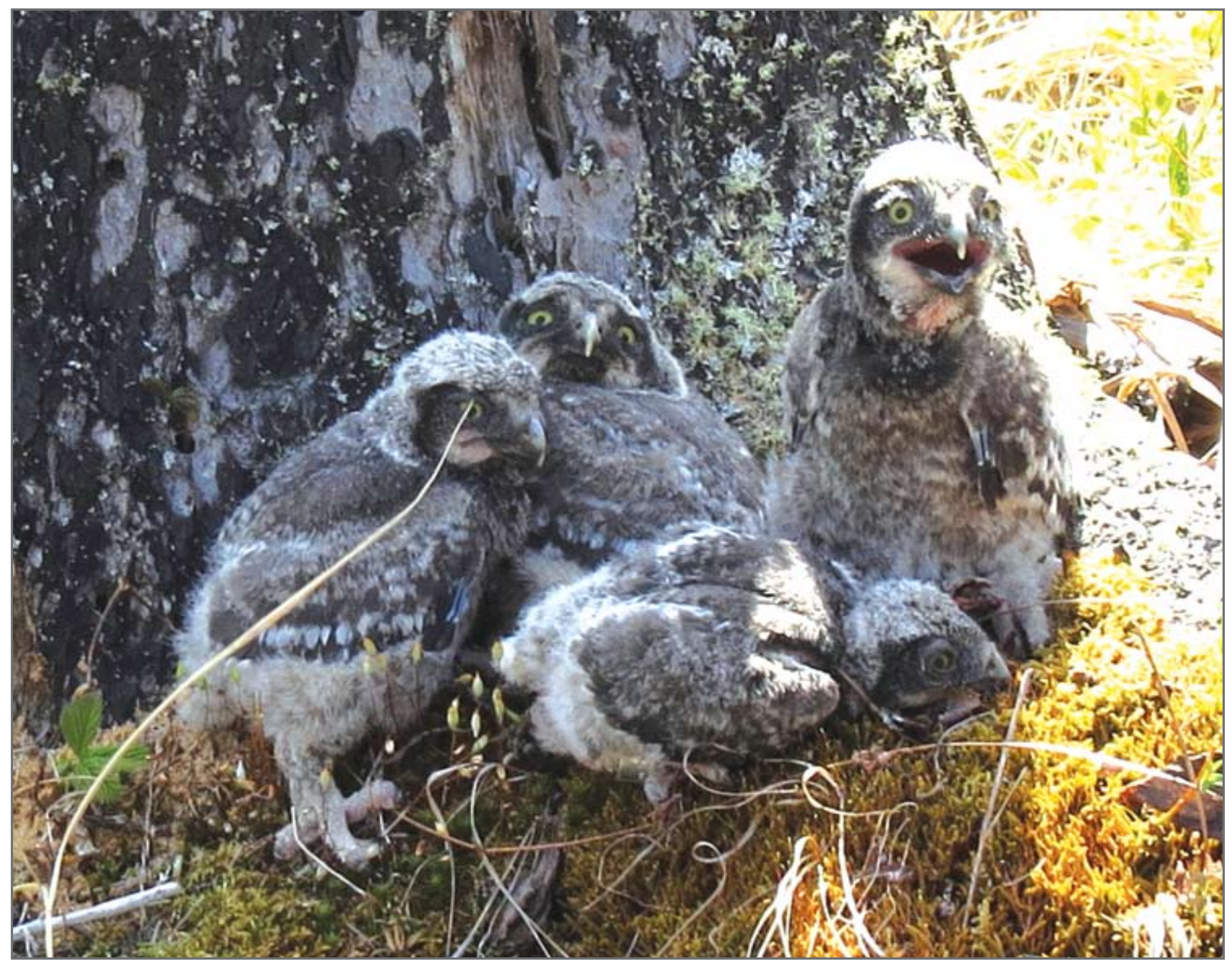

Northern Hawk Owl chicks at time of banding (June 3, 2015). Photo credit: Harold Fisher

\title{
NORTHERN HAWK OWLS USE NEST BOX
}

\section{Harold Fisher}

RR 4, Site 1, Comp 231

Prince Albert, SK S6V 5R2

hfisher@skyvelocity.ca

During the spring of 2010, Marten Stoffel and I constructed seven nest boxes for Northern Hawk Owls (Surnia ulula). Our hope was to erect these boxes in an area frequented by this species and to have them in place for the 2010 breeding season. The boxes were placed along the Bittern Lake Road approximately $28 \mathrm{~km} \mathrm{NW}$ of the village of Candle Lake with a spacing of $1 \mathrm{~km}$ or more, and at a height of approximately
$5 \mathrm{~m}$. The area was burned over by a forest fire circa 1995 and was characterized by burned snags, deadfall and new growth less than a metre in height. Previous visits to the area had shown good numbers of Northern Hawk Owls present during the breeding season.

The boxes were constructed of rough spruce lumber. Inside dimensions of the boxes were $20 \mathrm{~cm} \times 20 \mathrm{~cm} \times 51 \mathrm{~cm}$ high. The front of the box was left open, with a $10 \mathrm{~cm}$ board across the opening to contain the nesting material.

We inspected the boxes for occupancy each year in the spring, but until 2015 none of them had been used. All the boxes except one were installed on dead trees in the open burn and, by 2015 , more than half of the nest trees had blown down. Where Northern Hawk Owls were present in fairly good numbers during the first years after we installed the nest boxes, their numbers declined by 2014 and we were unable to locate any in that area after the spring of 2014.

On May 4, 2015, Marten, Brent Terry and I checked out the area once again and found no Northern Hawk Owls present. We checked the remaining nest boxes for occupancy 
as well, but NB01 was in a wet muskeg, and with the apparent absence of hawk owls in the area, we 'checked' this one from the road with binoculars. Almost as an afterthought, Marten played the Northern Hawk Owl audio from the road and received a response almost immediately. When we walked in toward the nest box a short while later, we observed a hawk owl leave a perch some $100 \mathrm{~m}$ away and fly directly to the box. We used a nest inspection camera to confirm activity and found the box to contain five eggs.

On May 23, 2015, Faith Fraser and I returned to determine the progress of the nest. We used the nest inspection camera once again and determined that the nest now contained four recently hatched chicks and one unhatched egg. We captured and banded the female at this time.

On June 3, 2015, Brent Terry and I banded the four flightless young, estimated at 13 to 18 days of age and ranging in weight from 195 to $241 \mathrm{~g}$. We believe this to be the first documented occurrence of a Northern Hawk Owl using an artificial nest box erected for that purpose in North America.

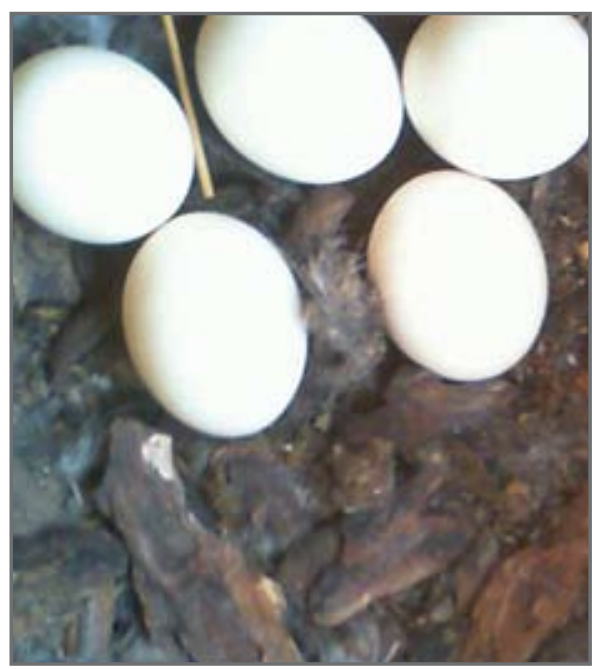

Northern Hawk Owl nest contents (taken with nest inspection camera on May 4, 2015). Photo credit: Harold Fisher

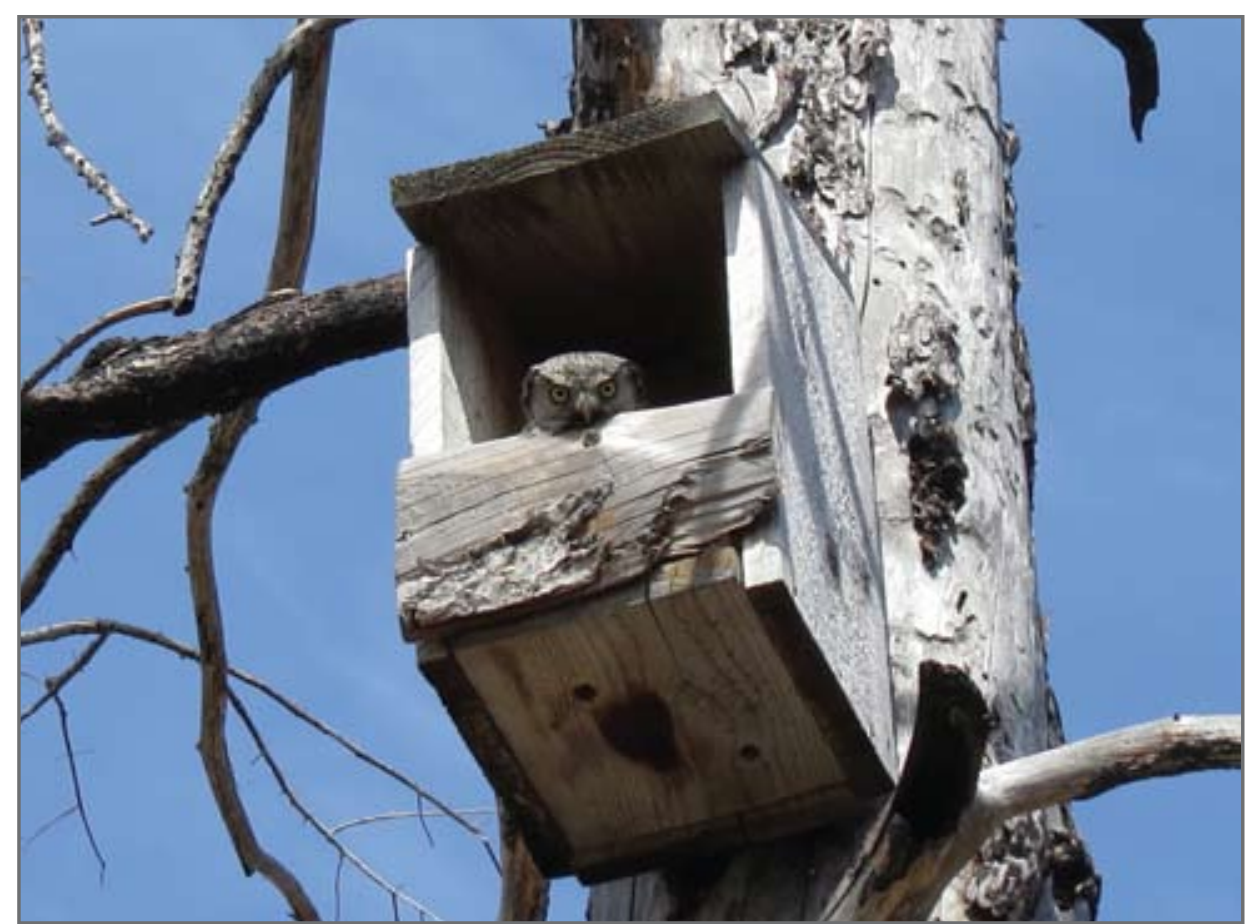

Northern Hawk Owl female in nest box (May 20, 2015). Photo credit: Harold Fisher

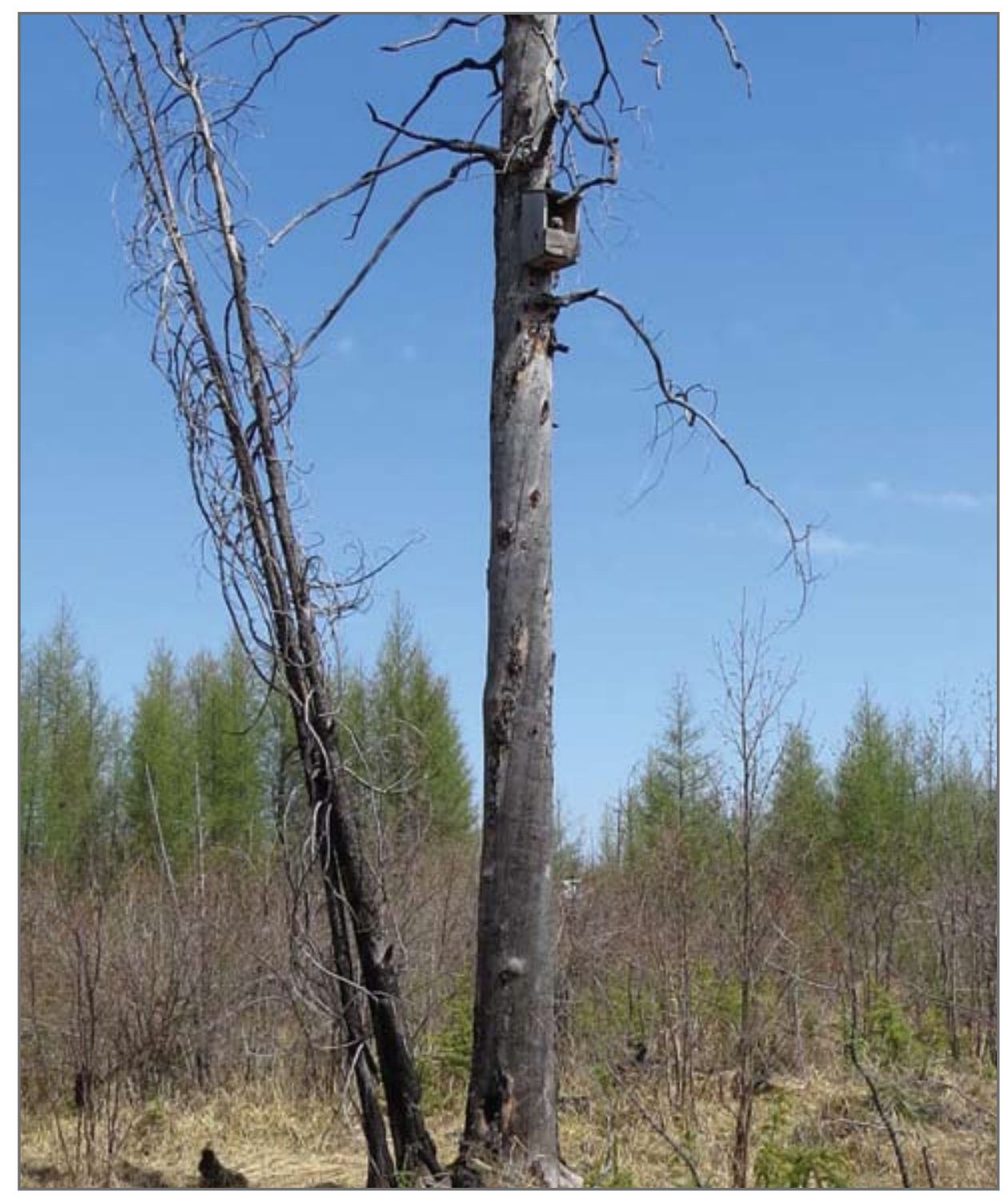

Placement of nest box on fire-killed Jack Pine (May 20, 2015). Photo credit: Harold Fisher 